\title{
Techniques on Translation of Cultural Terms and Post-modernism
}

\author{
Gagan Singh Air, Lecturer \\ Kathmandu Shiksha Campus
}

\begin{abstract}
Translation is a process of rendering meaning from one language to another language and translation procedures are the technical strategies adopted by the translator to achieve the closet possible equivalent. In this paper an attempt has been made to evaluate the techniques of translation of cultural terms offered by New mark that have been employed in translating cultural words. This paper also aims to have an argument on the techniques of translation that focus on target readers in postmodernism. It has been found that in translating cultural terms, ten different techniques are found to have been employed in translating cultural words. Literal translation is mostly used and claque is the least used technique. There is triangular relationship among the translator, the text and the reader. A translator should remove the spectacle of domination and accept the foreign culture and source culture with respect in postmodernism.
\end{abstract}

Keywords: Cultural bound word, Source language, Target language, Translation strategies or techniques and Post-modernism.

\section{Introduction}

Translation is the process of translating the message or idea or the meaning of a text of one language into another one. The term "translation" connects the art of recomposing a work in another language without losing its original flavor. The American theorist Lawrence Venuti defines translation as "a process by which the chain of signifier that constitutes the source-language text is replaced by a chain of signifier in the target language which the translator provides on the strength of an interpretation" (Venuti ,1995).Wills (1982, p.112) defines translation as "a procedure which leads from a written Source Language Text (SLT) to an optionally equivalent Target Language Text(TLT) and requires syntactic, semantic, stylistic and text pragmatic comprehension by the translator of the original text. Newmark (1981) says "the twentieth century has been called the age of translation."In the words of Bhattarai (2000) "translating is primarily an art of transforming message from one language to another or into some other dialects of the same language that are distanced by time or space". Translation is both linguistic and cultural activity.

60 I ििक्षाशास्त्र सौरम, अङ्क २१, २०१ट। २०६४-०६६ 


\section{Objective}

The major objectives of this article is to evaluate the techniques of translation of cultural terms offered by Newmark that have been employed in translating cultural words in fictional texts. This paper also aims to have an argument on the technique of translation that focus on target readers in post-modernism. It tries to give multicultural sense in translator's mind despite having many flaws like destruction of original meanings.

\section{Methodology}

To accomplish the above objectives, cultural words have been selected through random sampling procedure from both version of the novel "The Gorkha's Daughter". Selected words have been analyzed interims of Newmark category.

\section{Cultural-bound words}

Newmark introduced the term 'cultural word' that refers to words in which the readership is unlikely to understand. He also categorized the cultural words viz 1) Ecology: flora, fauna, hills, winds, plains .2) Material Culture: food, clothes, houses and towns, transport3) Social Culture: work and leisure4) Organization customs, activities,procedures, concepts: • Political and administrative $\bullet$ Religious $\bullet$ artistic and 5)Gestures and habits

\section{Concepts of translation and translating nepali words}

Different countries do have their own style regarding translation techniques. Russians basically use contextual correspondence, equivalence though they use other techniques as well. Russian model is similar to language and parole relationship. Equivalence is possibility in some situations but exact equivalence may not be possible because no languages are identical. Linguistic deficit is found in other language that creates problem in exact replacement. Canadian adopts techniques like concretization, logical formation, compensation, borrowing, claque, literal translation, modulation, transposition and adaptation. They consider that logical formation is more important while translating a translator should forget what is there and have to consider what they mean. Antonymic translation is negatively defining translation. Newmark (1988) has given twelve translation procedures: Transference, Cultural equivalent, Neutralization, Literal translation, Naturalization, Componential analysis, Deletion, Couplet, Accepted standard translation, Paraphrase and Classifier. Harvey and Higgins (1992), (as cited in Awasthi, Bhattarai and Khaniya, 2011, p.48) provided the following major techniques of translation of cultural terms: Exoticism, Claque, Cultural borrowing, Communicative, transplantation. Everest has no meaning until we consider sea. Sanothiyo is compared with not big, 'lagatar' can be compared with without a break 
in target language, in English compensation is very heavy, useful term in translation. There is cultural gap. Gaps are inevitable, only to try to fill the gap is compensation, we compensate with similar meaning or equivalent terms like 'Baptism' is replaced by nawran in Nepali. Americans have their own methods to translate any source language into target language. Matching, zigzagging, excrescence, re locking, reordering and recoding are mainly focused techniques by Americans. In this article my elaboration of translation techniques is based on the techniques of Scan-Paul Vinay and jean Darbelnet mentioned on the topic "A methodology for Translation". According to Nida (1964) linguistic deficit makes more problems in translation. The English word marker is also called marker in Nepali, Hindi and Sanskrit .So rearrangement of words does not make differences in meaning but not possible in English.'Aphutagaiyo ' passive of Nepali sentence can be possible even in transitive verb but is not possible in English." Ram le Ravan lai mare Ram le Ravanlai ,raravanlairamle mare 'are possible although there are slight differences but not actually possible in English. In some translation it may be possible to transpose the source language message element into the target language, because it is based on either (i) parallel categories in which case we can speak of structural parallelism or (ii) on parallel concepts, which are the result of meta-linguistic parallelism but translation may also notice gaps or meta-linguistic differences, certain stylistic effects cannot be transposed into the TL without upsetting the syntactic order or even the lexis .

\section{Modulation}

It is a variation of the forms of the message, obtained by a change in the point of view. This change can be justified when, although a literal, or even transposed, translation result in a grammatically correct utterances, it is considered unsuitable, unidiomatic or awkward in the TL change the point of view, signified remains the same ,signifer can be changed .sunnelaisoonkomala... I have done mystery, see the mouse ran .... This short translation dictionary can not give exact meanings word because , that is bicultural idea "aphnothaileebadherarakhnuarkolai dosh nadinu" This can't get into a closed mouth" when they became clinches. The difference between fixed and free modulation is one of degree. In case of fixed modulation,the translators with a good knowledge in the both languages, freely use this method .True modulation doesnot actually become fixed until it is referred to in dictionaries and grammars and is regularly taught.

\section{Literal translation}

Literal translation ranges from word to word level up to sentence to sentence. It preserves linguistic meaning of source language text. It is form-oriented translation and makes no sense in most of the cases specifically in translating idiomatic and phatic expressions. For example, SL (English): He bit tongue.TL (Nepali): uslejibroṭokyo. 


\section{Transference/Borrowing}

Transference (loan word, transcription) is the process of transferring a SL word to a TL word as a translation procedure. It includes transliteration, which relates to the conversion of different alphabets, e.g. Russian, Greek, Chinese, etc. into English. According to New mark (1988: 82), normally names of people, places and countries, names of newspapers, names of institutions and companies, street names, inventions, brand names, etc. are transferred. In the process of translation the translator transfers the word to show the respect for the SL culture. For example,SL (English): Opium TL (Nepali): aphīm

\section{Substitution}

When two cultures display a partial overlap rather than a clear cut presence or absence of a particular element of culture, this procedure is adopted. In other words, the translator replaces the cultural elements with similar words or near equivalent word or generic word/meaning. . For example,SL (English): Basket TL (Nepali): toko

\section{Paraphrasing/Definition}

In this procedure, SL terms are replaced by the short definition or paraphrase. This is an amplification or explanation of the meaning of a segment of the text. Normally, if the TLT has not the exact substitution for the source language term, the SL term is replaced by definition or description. For example, SL (English): Pork balls TL (Nepali):sũgurkāmāsukākwāpkhāneḍallā.

\section{Claque}

In this procedure, each unit of source language is translated into the equivalent unit in another language (i.e. TL). The unit of translation for this procedure may be a morpheme, a word, a phrase or even a short sentence. It follows the word order of the SLT. For example,SL (English): Earth God TL (Nepali): prīthvīmātā

\section{Blending}

In this process, words are coined through borrowing one constituent from the SL or donor language (DL) and reproducing or translating the other constituent of the construction. In it we find the fusion of two words. For example,SL (English): Silver dollar TL (Nepali): cāñīināḍalar

\section{Couplets}

The combination of two procedures (Borrowing + Literal) is called couplet. It deals with a single problem. They are particularly common for cultural words if transference is combined with a functional or a cultural equivalent. 


\section{Naturalization}

This procedure succeeds transference and adopts the SL word first to the normal pronunciation, then to the normal morphology of the TL. For example,SL (English): China(Nepali): cīn

Addition In this technique of translation, some words are added in the TL text. This procedure is necessary in translation of the implicit element in the culture. It makes implicit information explicit.

\section{Post-modernism}

Post-modernism has emerged against the structuralism that can be seen as counter movement even in Saussure's linguistic theory in the beginning. This concept has come with the emergence of globalization which rejects logo centralism. Translator and translation are both freely emancipated from the slavery of powerful agencies and rule and regulation of translation. Postmodernist writers break down every conceivable boundary of discourse by fusing forms and confusing different realm, so the post-structuralists deny the distinctions between the traditional order of discourse. Derrida advocated this theory against structuralism to give more priority to all things without saying centrality and peripheral because text has no finality. In other words it is opposition to the notion of centrality, boundaries between high and low form art, objectivity, absolute the truth and materialistic supremacy is post-modernism. It actually rejects perfection,wholeness, completeness and singularities. Venuti(1999) quotes de Man who says that the original text 'cannot be definite since it cannot be translated.' It shows the infinite possibilities of meaning and reinterpretation and even there is polysemous translation in present era . Another scholar Kirkwood(1995) mentions 'appallingly bad translation are bordering on the unintelligible'( $p, 104)$. According Klages(2007) the post-modernism is the critique of grand narrative, the awareness that such narrative serves to mask the contradictions and instabilities that are inherent in any organization or practice. From post-modernism the grand narrative does have inauthentic representation of marginalized, poor and women. If we look at Mahabharat.,Ramayan, Bible, Ved (grand narratives) and Kuran,, there is subordination of powerless people and women are represented as second position holder in society.

Aforementioned ideasshow that the post-modernism has lost the faithfulness towards the grand narrative so this era or post-modernism is characterized by the emergence of little narratives. 


\section{Techniques used in translation of ecological terms}

Identification of the techniques used in translation for the selected terms are presented here.

Table 1: Techniques used in translation of ecological terms

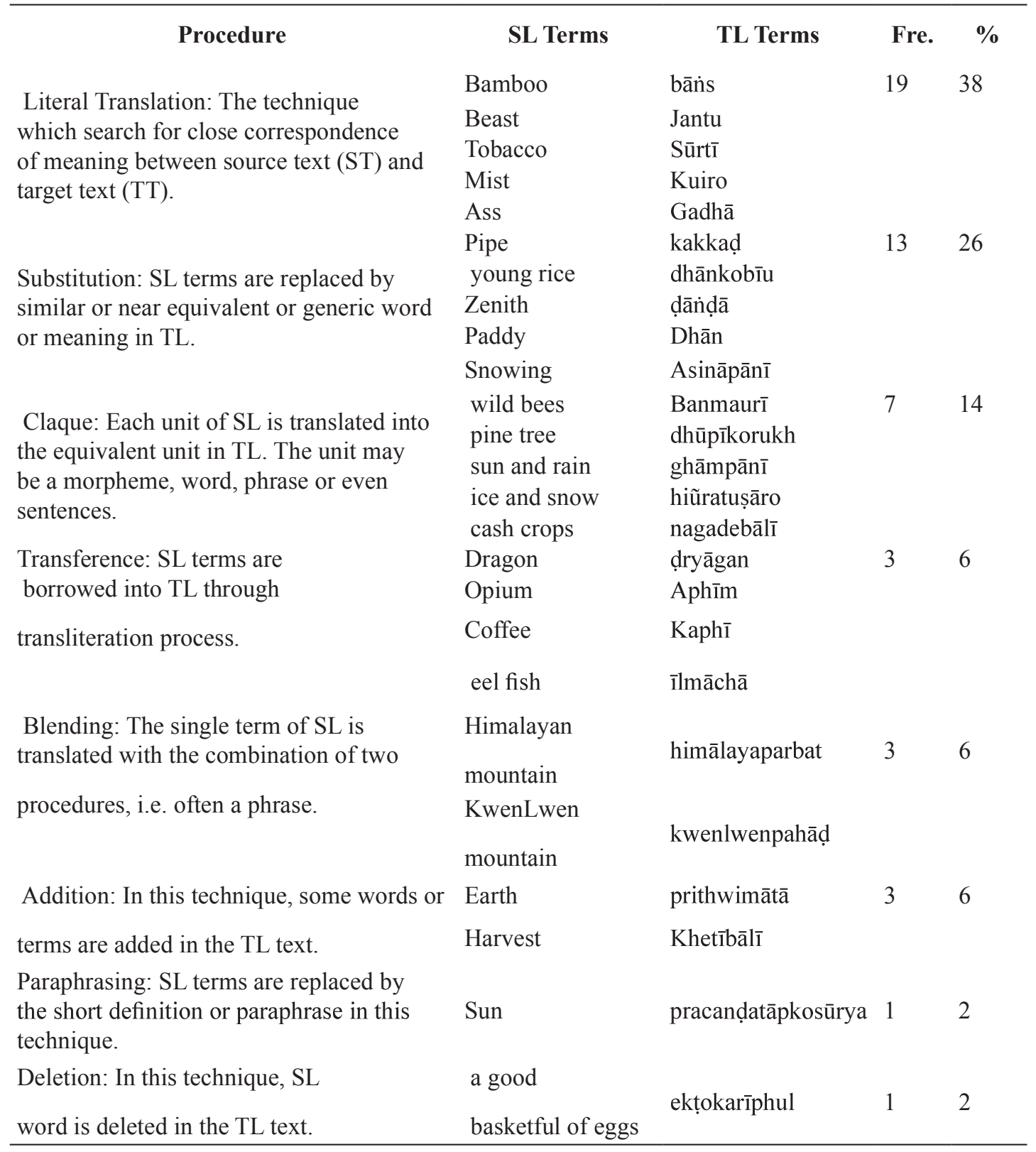

(Air, 2016)

The above table shows eight different techniques which are used by the translator in the process of translating the ecological terms of source language text into the target 
language text. Some techniques are frequently used whereas some others are rarely used. So the researcher presented more examples of frequently used techniques whereas less examples of rarely used techniques in the above table. Among the eight different techniques, literal translation is mostly used which has $38 \%$ and paraphrasing/definition and deletion are the least used techniques, i.e. $2 \%$ for all two. Substitution is the second widely used technique which has 13 percent.

\section{Techniques used in translation of terms.}

In the process of translating the terms under material cultural, nine different techniques are used by the translator. These techniques have been presented in the following table with some examples.

Table 2: Techniques used in translation of terms of material culture (artifacts)

\begin{tabular}{|c|c|c|c|c|}
\hline Technique & SL Terms & TL Terms & Fre. & $\%$ \\
\hline \multirow[t]{5}{*}{ Literal Translation } & bread & roțī & 17 & 34 \\
\hline & dirty & Phohar & & \\
\hline & veranda & Bārdalī & & \\
\hline & hut & Chāpro & & \\
\hline & transport & Āwatjāwat & & \\
\hline \multirow[t]{5}{*}{ Substitution } & basket & doko & 12 & 24 \\
\hline & noodles & Cāucāu & & \\
\hline & Hat & țopī & & \\
\hline & carriages & Baggī & & \\
\hline & spindle & Carkhā & & \\
\hline \multirow[t]{4}{*}{ Claque } & worn knife & Bhuttechurī & 6 & 12 \\
\hline & bamboo silver & bānskosinkā & & \\
\hline & bamboo bars & bānskolāțhī & & \\
\hline & sacks & Borā & & \\
\hline \multirow[t]{3}{*}{ Transference } & ricksha & Rikśā & 4 & 8 \\
\hline & chopisticks & capasțîk & & \\
\hline & cake & Kek & & \\
\hline \multirow[t]{3}{*}{ Addition } & rags & Jhutrāthāńnā & 4 & 8 \\
\hline & girdle & Ijārkothailī & & \\
\hline & knife & Churiracuppī & & \\
\hline \multirow[t]{2}{*}{ Blending } & cotton coat & sūtīkokoṭ & 2 & 4 \\
\hline & cot and trouser & koțrasuruwāl & & \\
\hline Definition & pork balls & $\begin{array}{l}\text { Sūgurkāmāsukā } \\
\text { kwāpkwāpkhāneḍallā }\end{array}$ & 2 & 4 \\
\hline $\begin{array}{l}\text { Couplets: It is the use of two } \\
\text { techniques for dealing with a } \\
\text { form of SL into TL. }\end{array}$ & mill & mil (ghațtajāto) & 2 & 4 \\
\hline Deletion & short-handled scythe & Hãsiyā & 1 & 2 \\
\hline
\end{tabular}


The above table shows nine different techniques which are used by the translator in the process of translating the terms under material culture of source language text into the target language text. Some techniques are frequently used whereas some others are rarely. Nine different techniques have been applied to translate these 50 terms. Out of these 9 techniques, literal translation is the most widely used technique, i.e. $34 \%$ and deletion is the least used technique, i.e. $2 \%$.

\section{Techniques used in translation of terms of mythological pattern}

Techniques are presented in the following table with some examples.

Table 3: Techniques used in translation of terms of mythological pattern

\begin{tabular}{|c|c|c|c|c|}
\hline Technique & SL Terms & TL Terms & Fre. & $\%$ \\
\hline \multirow[t]{5}{*}{ Literal Translation } & Temple & Mandir & 18 & 36 \\
\hline & Virgin & Kumārī & & \\
\hline & Heaven & Swarga & & \\
\hline & Wife & Swāsnī & & \\
\hline & Dowry & Dāijo & & \\
\hline \multirow[t]{5}{*}{ Substitution } & Pair & Dampatī & 14 & 28 \\
\hline & he and his wife & Logneswāsnī & & \\
\hline & God & Bidhatā & & \\
\hline & Soul & $\bar{A}$ tmā & & \\
\hline & Corpse & $\mathrm{Sab}$ & & \\
\hline \multirow[t]{5}{*}{ Claque } & earth god & prithwīmātā & 8 & 16 \\
\hline & new year & nayābarșa & & \\
\hline & sticks of incense & dhūpkāsinkā & & \\
\hline & death-like & murdākojasto & & \\
\hline & sacred scars & pabitradāg & & \\
\hline \multirow[t]{4}{*}{ Addition } & starving & anikālpīḍit & 6 & 12 \\
\hline & Burials & antyesțikriyā & & \\
\hline & marriage & Śubhabiwāha & & \\
\hline & Wife & Dharmapatnī & & \\
\hline Transference & Buddha & Buddha & 1 & 2 \\
\hline Blending & Taoist temple & tāosampradāya & 1 & 2 \\
\hline Definition & Coffin & $\begin{array}{l}\text { mritaśarīr } \\
\text { rākhnebākas }\end{array}$ & 1 & 2 \\
\hline Deletion & funeral fire & Citā & 1 & 2 \\
\hline
\end{tabular}

The above table shows eight different techniques which are used by the translator in the process of translating the terms of mythological pattern of source language text into the target language text. For transmission of these fifty terms, 8 different techniques were employed. Among these, 8 different techniques, literal translation is the most widely used technique, i.e. $36 \%$ and transference, blending, definition, and deletion are the least used techniques. 


\section{Techniques used in translation of terms of social culture and organizations}

In the process of translating terms of social culture and organizations, eight different techniques have been used by the translator. These techniques are presented in the following table with some examples.

Table 4: Techniques used in translation of terms

\begin{tabular}{|c|c|c|c|c|}
\hline Technique & SL Terms & TL Terms & Fre. & $\%$ \\
\hline \multirow[t]{5}{*}{ Literal Translation } & Soldier & Sipāhī & 22 & 44 \\
\hline & Quarrel & jhagaḍā & & \\
\hline & School & Bidhyālaya & & \\
\hline & Dowry & Dāijo & & \\
\hline & Emperor & Bādśāha & & \\
\hline \multirow[t]{5}{*}{ Substitution } & wooden head & ghanțāuke & 9 & 18 \\
\hline & Gateman & dhoke & & \\
\hline & Court & Darabār & & \\
\hline & Madam & Āmā & & \\
\hline & distant parts & Muluk & & \\
\hline \multirow[t]{4}{*}{ Claque } & old mistress & būụhīmāliknī & 6 & 12 \\
\hline & land proprietor & Jamīndār & & \\
\hline & ideal state & ādarśarājya & & \\
\hline & old lord & būḍhomālik & & \\
\hline \multirow[t]{3}{*}{ Transference } & stone bridge & sțonbrīj & 4 & 8 \\
\hline & Pence & Pens & & \\
\hline & Feet & phit & & \\
\hline \multirow[t]{3}{*}{ Addition } & War & Yuddhakalā & 4 & 8 \\
\hline & Teacher & māsțarsahib & & \\
\hline & birth feast & janmadiwaskobhoj & & \\
\hline \multirow{2}{*}{$\begin{array}{l}\text { Naturalization: In this } \\
\text { technique one naturalizes } \\
\text { the TL terms into SL terms }\end{array}$} & China & Cīn & 3 & 6 \\
\hline & Russia & Rus & & \\
\hline Couplets & Street of Bridges & $\begin{array}{l}\text { sttrītaphbrījes } \\
\text { (pulkosaḍak) }\end{array}$ & 1 & 2 \\
\hline Blending & silver dollar & cāndīkāọalar & 1 & 2 \\
\hline
\end{tabular}

(Air, 2016)

The above table shows eight different techniques which are used by the translator in the process of translating the terms of social culture and organizations of source language text into the target language text. Some techniques are frequently used whereas some others are rarely. For the translation of these 50 terms, 8 different techniques were employed. Among these 8 different techniques, literal translation was the most widely used technique, i.e. $44 \%$ and couplets, and blending were the least used techniques, i.e. $2 \%$. In terms of descended order of frequency, the techniques of translating the terms of social culture and organizations could be graded as literal translation, substitution, claque, transference, addition, naturalization, couplets, and blending. 


\section{Conclusions}

On the basis of analysis and interpretation of the data, the following findings have been summed up. In translating cultural terms, ten different techniques (literal translation, substitution, claque, transference, addition, blending, definition, couplet, deletion and naturalization) are found to have been employed in translating cultural words in the novel. In terms of merit order of frequency the techniques of translation of cultural words could be graded as literal translation (38.4\%), substitution $(23.2 \%)$, claque $(13.2 \%)$, addition $(8.4 \%)$, transference $(5.6 \%)$, definition $(3.6 \%)$, blending $(2.8 \%)$, deletion $(2.4 \%)$, couplet $(1.2 \%)$ and naturalization $(1.2 \%)$.Literal translation is the most widely used technique in translating ecology, material culture (artifacts), social culture and organizations, conceptual terms and mythological pattern. Substitution is the widely used technique in translating mythological pattern than other cultural categories. Post-modernism has presented a radical reconstruction of the translation theory to subverted created dichotomies and binary features of modernism or colonial concept .Understanding the target reader is very important in setting strategies while translating the historical novel. The problem of context is one of the major problems in the process of translation. There is triangular relationship among translator, text and the reader. A translator should remove the spectacle of domination and accept the foreign culture and source culture with respect.

\section{References}

Air, C.B (2016) A study on translation of cultural terms: A case of the book Gorkha's Daughter. Unpublished M.Ed. thesis, department of English education, Tribhavan University.

Bassnett McGuire, S. (1980). Translation studies. London: Methuen and Co. Ltd.

Bhattarai, A. (2001). 'Writing a research proposal', Journal of NELTA. Vol.- 6, No. 1. P 4551. Kathmandu.

Bhattarai, G.R.(1997). In Other Words: Sense versus words as unit of literary translation (With Special Reference Nepali-English Poetic Texts). A Ph.D. Thesis; India: University of Hyderabad.

Catford, J.C. (1965). A linguistic theory of translation. Oxford: OUP.

Holmes, J.S., Lambert, J. and Lefevere, A(Eds.) Literature and translation. The Hague. Mounton

Newmark, P. (1981). Approaches to translation. Oxford: Pergamon Press. (1988). A textbook of translation. New York: Prentice Hall.

Nida, E.A. (1964). Towards science of translating. Leiden: E. J. Brill.

Procter, P. (ed.) (1995). Cambridge international dictionary of English. Cambridge: CUP.

Richards, J. et al. (1985). Longman dictionary of applied linguistics. London: Longman.

Sapir, E. (1963). Language: An Introduction to the Study of Speech. London: Granoda Publishing.

Wardhaugh, R. (1986). An introduction to sociolinguistics. Oxford: Basil Blackwell,

Wilss, W. (1982). The Science of Translation: Problems and Methods. Tubingen: Guntar Narrverlag. 